\title{
Pengaruh Aplikasi Bakteri Endofit Terhadap Perkembangan Penyakit Darah (Ralstonia solanacearum Phylotipe IV) pada Tanaman Pisang
}

\section{The Influenceof Endophytic Bacteria Application on the Developmentof Blood Disease (Ralstonia solanacearum Phylotipe IV) on Banana}

\author{
Husda Marwan*, Rainiyati, Sri Mulyati \\ Program Studi Agroekoteknologi, Fakultas Pertanian, Universitas Jambi, Jl. Jambi-Muara Bulian KM 15, Muaro Jambi, \\ Propinsi Jambi 36361 Indonesia \\ *Email Penulis Korespondensi: husda_marwan@unja.ac.id
}

Tanggal submisi: 25 Mei 202; Tanggal penerimaan: 26 Juni 2020

\begin{abstract}
Endophytic bacterium EAL15 and EKK22 isolated from banana plants can suppress the development of blood diseases caused by Ralstonia solanacearum Phylotype IV in banana. This study aims to obtain the best liquid media for multiplying endophytic bacterial isolates EAL15 and EKK22, as well as the effect of the application of endophytic bacteria to the development of blood diseases in banana plants in the field. The liquid media tested were: coconut water waste + peptone, coconut water waste, and peptone. The application of endophytic bacterial suspension on Raja Bulu banana seedlings was done one month before planting, during planting, and 3 months after planting. Inoculum of $R$. solanacearum was inoculated on roots and banana flowers. Observations were made on the number of endophytic bacterial populations in each liquid media, the severity of blood diseases in plants and the incidence of blood diseases in bananas. The results showed that the liquid media of coconut water waste +peptone was the best medium for multiplying endophytic bacterial isolates. The application of endophytic bacteria influences the severity of blood diseases in banana plants and the incidence of diseases in bananas. The frequency of application of endophytic bacteria has no effect on the development of blood diseases in plants and bananas.
\end{abstract}

Keywords: banana; blood disease; endophytic bacteria

\section{ABSTRAK}

Isolat bakteri endofit EAL15 dan EKK22 yang diisolasi dari tanaman pisang mampu menekan perkembangan penyakit darah yang disebabkan oleh Ralstonia solanacearum Phylotipe IV pada bibit pisang. Penelitian ini bertujuan untuk mendapatkan media cair terbaikuntuk memperbanyak isolat bakteri endofit EAL15 dan EKK22, serta pengaruh aplikasi bakteri endofit terhadap perkembangan penyakit darah pada tanaman pisang di lapangan. Media cair yang diuji yaitu : limbah air kelapa + pepton, limbah air kelapa, dan pepton. Aplikasi suspensi bakteri endofit pada bibit pisang Raja Bulu dilakukan satu bulan sebelum ditanam, saat tanam, dan 3 bulan setelah tanam. Inokulum $R$. solanacearumdiinokulasikan pada perakaran dan bunga pisang. Pengamatan dilakukan terhadap jumlah populasi bakteri endofit dalam masing-masing media cair, keparahan penyakit darah pada tanaman dan kejadian penyakit darah pada buah pisang. Hasil penelitian menunjukkan bahwa media limbah air kelapa + pepton merupakan media terbaik untuk memperbanyak isolat bakteri endofit. Aplikasi bakteri endofit berpengaruh terhadap keparahan penyakit darah pada tanaman pisang dan kejadian penyakit pada buah pisang. Frekuensi aplikasi bakteri endofit tidak berpengaruh terhadap perkembangan penyakit darah pada tanaman dan buah pisang.

Kata kunci: Bakteri endofit, penyakit darah, pisang

\section{PENDAHULUAN}

Penyakit darah merupakan salah satu penyakit penting pada tanaman pisang yang disebabkan oleh bakteri Ralstonia solanacearum Phylotipe IV (Fegan dan Prior, 2006) yang dapat menyebabkan tanaman mati atau menghasilkan buah pisang yang tidak dapat dikonsumsi (Supriadi, 2005). Tingkat penularan patogen yang tinggi menyebabkan penyakit ini dapat menyebar luar di areal tanaman pisang. Bakteri patogen dapat ditularkan oleh serangga pengunjung bunga pisang dan melakukan penetrasi pada nektartoda serta luka pada 
lampang bunga pisang yang tidak menjadi buah (Buddenhagen dan Elsaser, 1962).

Menurut Semangun (2000), pengendalian penyakit darah dapat dilakukan melalui eradikasi lahan secara rutin dengan membongkar sisa-sisa akar dari rumpun tanaman yang sakit, tidak menanam pisang pada areal bekas tanaman sakit selama 2 tahun, menanam bibit yang diambil pada tanaman induk yang sehat, pemeliharaan drainase untuk mencegah penyebaran patogen melalui air, dan desinfektan alatalat yang digunakan untuk bercocok tanam. Pembungkusan tandan bunga dan membuang bunga jantanmerupakan teknik pengendalian yang direkomendasikan untuk mencegah penularan bakteri $R$. solanacearum melalui serangga pengunjung bunga (Hermanto et al., 2013). Teknik pengendalian ini cukup efektif untuk mencegah penularan penyakit darah tetapi pelaksanaannya masih sulit dilakukan oleh petani. Oleh sebab itu perlu dikembangkan teknik pengendalian lain yang lebih mudah diaplikasikan oleh petani.

Penggunaan agens hayati untuk mengendalikan penyakit darah merupakan teknik pengendalian yang dapat dikembangkan karena lebih mudah diaplikasikan dan bersifat ramah lingkungan. Bakteri endofit merupakan salah satu kelompok mikroba yang saat ini banyak dikembangkan sebagai agens pengendalian hayati penyakit tanaman. Bakteri endofit dilaporkan mampu menginduksi ketahanan tanaman terhadap patogen tanaman danmeningkatkan pertumbuhan tanaman (Hallmann, 2001)karena bakteri mampu memfiksasi nitrogen (Bashan dan de-Bashan 2005), meningkatkan ketersediaan mineral, menghasilkan fitohormon (Hurek et al. 2002), dan produksi siderofor (Sessitsch et al. 2004).

Pemanfaatan bakteri endofit untuk mengendalikan penyakit pada tanaman pisang sudah banyak dilakukan. Beberapa hasil penelitian menunjukkan bahwa bakteri endofit mampu menginduksi ketahanan tanaman pisang terhadap penyakit Banana Bunchy Top Virus (Harish et al., 2008), layu Fusarium (Lian et al., 2008) dan penyakit darah (Marwan et al., 2011). Isolat bakteri endofit EAL15 dan EKK22 yang diisolasi dari pisang Ambon Lumut dan Kepok Kuning mampu menekan kejadian penyakit sebesar 75,0 dan $83,3 \%$ serta mampu meningkatkan pertumbuhan bibit pisang Cavendish (Marwan et al., 2011). Isolat tersebut juga diketahui mampu mengimbas ketahanan tanaman pisang terhadap bakteri $R$. solanacearum melalui peningkatan aktivitas enzim peroksidase (Marwan, 2014).

Untuk mengaplikasikan bakteri endofit pada tanaman diperlukan media perbanyakan bakteri yang dapat mengoptimalkan pertumbuhan sel bakteri. Keefektifan bakteri endofit dalam mengendalikan patogen juga dapat dipengaruhi oleh kemampuan bakteri mengkolonisasi perakaran dan jaringan tanaman.Penelitian ini bertujuan untuk mendapatkan media cair terbaik untuk memperbanyak isolat bakteri endofit EAL15 dan EKK22, serta pengaruh aplikasi bakteri endofit terhadap perkembangan penyakit darah pada tanaman pisang di lapangan

\section{METODE PENELITIAN}

Penelitian ini dilakukan di Laboratorium Agensia Hayati, Fakultas Pertanian Universitas Jambi dan lahan pertanian di Kelurahan Teratai, Kecamatan Muara Bulian, Kabupaten Batanghari, Provinsi Jambi. Bahanbahan yang digunakan adalah isolat bakteri endofit EAL15 dan EKK22, media Tryptic Soy Agar (TSA), pepton, air kelapa, bibit pisang Raja Bulu. Alat-alat yang digunakan dalam penelitian ini adalah autoclave, laminar airflow, shaker, dan spektrofotometer.

\section{Seleksi Media Perbanyakan Bakteri Endofit}

Isolat bakteri endofit diperbanyak dalam media limbah air kelapa dan media sintetik (pepton). Percobaan ini menggunakan Rancangan Acak Lengkap (RAL) dengan perlakuan kombinasi isolat bakteri endofit (Isolat EAL15 dan EKK22) dan media perbanyakan bakteri. Perlakuan dalam seleksi media perbanyakan bakteri endofit adalah: 1) Isolat bakteri EAL15 dalam media limbah air kelapa + pepton; 2) Isolat bakteri EKK22 dalam media limbah air kelapa + pepton; 3) Isolat bakteri EAL15 dalam medialimbah air kelapa; 4) Isolat bakteri EKK22 dalam medialimbah air kelapa; 5) Isolat bakteri EAL15 dalam media pepton; dan 6) Isolat bakteri EKK22 dalam media pepton.

Media air kelapa + pepton dibuat dengan melarutkan $5 \mathrm{~g}$ pepton dalam $1 \mathrm{~L}$ limbah air kelapa, sedangkan media pepton dibuat dengan melarutkan $5 \mathrm{~g}$ pepton dalam $1 \mathrm{~L}$ akuades. Masing-masing media perbanyakan disterilkan dalam autoclave pada suhu $121^{\circ} \mathrm{C}$ dengan tekanan $1 \mathrm{~atm}$ selama 15 menit.

Isolat bakteri endofit EAL15 dan EKK22 yang akan diperbanyak pada masing-masing media perlakuan, dibiakkan terlebih dahulu pada media TSA dalam cawan petri selama 48 jam pada suhu ruang, kemudian ditambahkan $10 \mathrm{~mL}$ akuades steril untuk membuat suspensi bakteri. Suspensi masing-masing isolat bakteri dibiakkan dalam media perbanyakan sesuai dengan perlakuan. Sebanyak $25 \mathrm{~mL}$ suspensi bakteri dicampurkan ke dalam $250 \mathrm{~mL}$ media perbanyakan dalam erlenmeyer $500 \mathrm{~mL}$ dan digoyang menggunakan shaker dengan kecepatan $100 \mathrm{rpm}$ selama 24 jam, kemudian media perbanyakan disimpan pada suhu kamar. Pengamatan optical density media perbanyakan dilakukan selama 4 minggu menggunakan spectrofotometer pada panjang gelompang $600 \mathrm{~nm}$. Pengamatan jumlah koloni bakteri dilakukan dengan metode pembiakan pada media TSA.

Media perbanyakan bakteri endofit yang menunjukkan pertumbuhan populasi optimal dalam masa penyimpanan selama 4 minggu akan digunakan untuk pengujian aplikasi bakteri endofit EAL15 dan EKK22 pada tanaman pisang di lapangan. 


\section{Uji Aplikasi Bakteri Endofit pada Tanaman Pisang}

Penanaman bibit pisang yang diaplikasikan dengan bakteri endofit dilakukan pada lahan yang belum digunakan untuk budidaya tanaman. Lahan percobaan dikelilingi oleh tanaman kelapa sawit dan karet, serta tidak ditemukan tanaman pisang. Perlakuan dalam penelitian ini adalah kombinasi isolatbakteri endofit (isolat EAL15 dan EKK22) dan frekuensi aplikasi pada bibit pisang Raja Bulu. Frekuensi aplikasi sebanyak 1, 2 dan 3 kali yaitu melalui perendaman bibit pisangsebelum tanam (aplikasi pertama), penyiraman suspensi bakteri pada perakaran tanaman saat tanam (aplikasi ke-2), dan penyiraman suspensi bakteri pada perakaran tanaman 3 bulan setelah tanam (aplikasi ke-3).

Bibit pisang yang digunakan dalam penelitian ini berasal dari hasil perbanyakan kultur jaringan. Aplikasi suspensi bakteri endofit pada bibit pisang sebelum tanam menggunakan metode Marwan et al. (2011). Akar bibit pisang direndam dalam $150 \mathrm{ml}$ suspensi bakteri endofit selama 6 jam, kemudian ditanam dalam polybag yang berisi $5 \mathrm{~kg}$ campuran tanah humus dan sekam bakar (perbandingan 2: 1 volume/volume). Bibit pisang kemudian dipelihara selama satu bulan. Bibit pisang tanaman kontrol direndam dalam akuades steril selama 6 jam, kemudian ditanam dalam polybag.

Bibit pisang yang digunakan untuk perlakuan penyiraman suspensi bakteri endofit pada saat tanam dan 3 bulan setelah tanam di tanam dalam polybag yang berisi $5 \mathrm{~kg}$ campuran tanah humus dan sekam bakar (perbandingan 2 : 1 volume/volume). Perlakuan penyiraman dilakukan dengan menyiramkan $100 \mathrm{ml}$ suspensi bakteri endofit ditanah perakaran tanaman. Tanaman kontrol disiram dengan $100 \mathrm{ml}$ akuades steril. Bibit pisang untuk setiap perlakuan ditanam dalam satu baris dengan jarak antar bibit $3 \times 3 \mathrm{~m}$. Lobang tanam berukuran $40 \times 40 \times 40 \mathrm{~cm}$ diisi dengan $5 \mathrm{~kg}$ pupuk kandang sapi dan diinkubasi selama 2 minggu sebelum tanam. Bibit pisang yang ditanam untuk masing-masing perlakuan adalah 10 bibit.

Inokulasi bakteri $R$. solanacearum dilakukan pada perakaran tanaman pisang yang belum berbunga $(6$ bulan setelah tanam) dan pada bunga pisang. Inokulum bakteri berasal kulit buah pisang yang bergejala penyakit darah. Persiapan inokulum BDB menggunakan modifikasi teknik Hadiwiyono (2010). Sel bakteri dalam air rendaman kulit buah terinfeksi diperoleh dari 5 irisan jaringan berukuran tebal $1 \mathrm{~cm}$ dengan diameter $5 \mathrm{~cm}$ yang direndam dalam $500 \mathrm{~mL}$ air steril dan kemudian didiamkan 12 jam untuk mendapatkan suspensi massa bakteri.

Inokulasi patogen pada perakaran tanaman pisang dilakukan pada dua sisi batang yang berlawanan. Tanah sekitar pangkal batang dibuka untuk mendapatkan perakaran dari tanaman pisang, kemudian 2-3 akar yang ditemukan dipotong dengan pisau steril. Pada akar yang telah dipotong, ditetesi sebanyak $5 \mathrm{~mL}$ suspensi inokulum bakteri patogen, kemudian akar ditutup kembali dengan tanah. Inokulasi bakteri patogen pada bunga dilakukan dengan cara menyemprotkaan $10 \mathrm{~mL}$ suspensi inokulum pada bunga pisang setelah kelopak bunga membuka dan terbentuk 2-3 sisir buah pisang. Setelah diinokulasi, tandan pisang dibungkus dengan karung plastik, dan diinkubasi selama 3 minggu. Setiap perlakuan diinokulasi sebanyak 3 tandan bunga yang mengalami proses pembungaan secara bersamaan.

Pengamatan keparahan penyakit darah pada tanaman yang diinokulasi melalui perakaran dilakukan 4 minggu setelah inokulasi. Perkembangan penyakit diamati berdasarkan indeks kelayuan (skor 0-4), dimana: $0=$ tanpa gejala, $1=$ satu daun layu, $2=$ dua daun layu, 3 = tiga daun layu, dan 4 = semua daun layu (tanaman mati). Keparahan penyakit darah pada tanaman pisang dihitung dengan rumus:

$$
\mathrm{KP}=\frac{\sum\left(n_{i} \times v_{i}\right)}{N \times Z} \times 100 \%
$$

dengan $\mathrm{KP}=$ Keparahan penyakit $(\%), n_{i}=$ tanaman dengan indeks kelayuan ke- $i$; $v_{i}$ indeks kelayuan ke- $i$; $N=$ jumlah seluruh tanaman yang diamati; $Z=$ indeks kelayuan tertinggi.

Pengamatan perkembangan penyakit darah pada buah pisang yang diinokulasi patogen dilakukan 3 minggu setelah inokulasi. Tandan buah yang telah dipanen dipisahkan antara jantung dan buah pisang. Masing-masing buah pisang dipotong sepertiga bagian ujungnya dengan pisau, kemudian diamati adanya gejala penyakit darah pada setiap buah dalam satu tandan pisang. Kejadian penyakit pada buah pisang dihitung berdasarkan jumlah buah yang menunjukkan gejala penyakit pada setiap tandan menggunakan rumus Agrios (2005) yaitu:

$$
K j P=\frac{a}{b} \times 100 \%
$$

dengan $K j P=$ Kejadian penyakit $(\%), a=$ jumlah buah yang menunjukkan gejala penyakit pada satu tandan pisang pada satu perlakuan, $b=$ jumlah buah pada satu tandan pada perlakuan yang sama

\section{HASIL DAN PEMBAHASAN}

\section{Seleksi Media Perbanyakan Bakteri Endofit}

Hasil pengamatan terhadap nilai obsorbansi masing-masing media perbanyakan bakteri endofit menunjukkan bahwa media perbanyakan berpengaruh terhadap optical density pada panjang gelombang 600 $\mathrm{nm}\left(\mathrm{OD}_{600}\right)$ selama proses penyimpanan. Setelah penyimpanan selama 4 minggu, nilai $\mathrm{OD}_{600}$ media perbanyakan bakteri endofit EAL15 dan EKK22 pada limbah air kelapa + pepton lebih tinggi dibandingkan media penyimpanan lainnya. Hal yang sama juga ditemukan pada pengamatan jumlah koloni bakteri melalui pembiakan suspensi dengan metode pengenceran berseri (Tabel 1). Penghitungan terhadap jumlah koloni bakteri endofit melalui metode pengenceran berseri dapat menunjukkan jumlah sel bakteri yang masih mampu melakukan pembelahan (viable). 
Tabel 1. Nilai absorbansi $\left(\mathrm{OD}_{600}\right)$ media perbanyakan bakteri endofit dan jumlah koloni bakteri endofit pada masingmasing media perbanyakan

\begin{tabular}{lcc}
\hline \multicolumn{1}{c}{ Isolat dan Media PerbanyakanBakteri Endofit } & $\begin{array}{c}\text { Nilai OD } 600 \text { Media } \\
\text { Pertumbuhan }\end{array}$ & $\begin{array}{c}\text { Jumlah koloni bakteri endofit } \\
\text { CFU/ml) }\end{array}$ \\
\hline EAL15 dalam media limbah air kelapa + pepton & $2,7426 \mathrm{a}$ & $15,75 \mathrm{a}$ \\
EKK22 dalam media limbah air kelapa + pepton & $2,6051 \mathrm{a}$ & $16,11 \mathrm{a}$ \\
EAL15 dalam media limbah air kelapa & $1,6956 \mathrm{~b}$ & $11,96 \mathrm{~b}$ \\
EKK22 dalam media limbah air kelapa & $1,8543 \mathrm{~b}$ & $8,91 \mathrm{~d}$ \\
EAL15 dalam media pepton & $0,4419 \mathrm{c}$ & $9,58 \mathrm{c}$ \\
EKK22 dalam media pepton & $0,2400 \mathrm{c}$ & $9,45 \mathrm{c}$ \\
\hline
\end{tabular}

Keterangan: Angka pada tiap kolom yang diikuti dengan huruf sama tidak berbeda nyata menurut uji DNMRT taraf 5\%

Tabel 1 menunjukkan bahwa jumlah koloni bakteri endofit EAL15 dan EKK22 pada media limbah air kelapa + pepton berbeda nyata dengan media perbanyakan lainnya setelah disimpan selama 4 minggu. Jumlah koloni bakteri endofit EKK22 pada media limbah air kelapa + pepton adalah 16,11 log CFU/mL $\left(1,28 \times 10^{16} \mathrm{CFU} / \mathrm{mL}\right)$, sedangkan jumlah koloni bakteri EAL15 adalah 15,75 log CFU/mL $\left(5,60 \times 10^{15}\right.$ $\mathrm{CFU} / \mathrm{mL}$ ).

Penambahan $5 \mathrm{~g}$ pepton (5\%) pada limbah air kelapa mampu meningkatkan jumlah koloni bakteri endofit EAL15 dan EKK22 setelah disimpan selama 4 minggu. Hal ini menunjukkan bahwa penambahan pepton pada limbah air kelapa mampu meningkatkan nutrisi yang dibutuhkan untuk pertumbuhan bakteri endofit.Hasil penelitian sebelumnya menunjukkan bahwa populasi bakteri endofit EAL15 dan EKK22 yang diperbanyak pada media limbah air kelapa saja lebih tinggi dibandingkan media sintetik TSA setelah disimpan selama 4 minggu (Marwan, 2014).

Hasil pengamatan terhadap jumlah koloni bakteri endofit EAL15 dan EKK22 pada media perbanyakan limbah air kelapa + pepton menunjukkan bahwa terjadi peningkatan jumlah koloni mulai penyimpanan 1 minggu sampai dengan 4 minggu. Pada media limbah air kelapa atau pepton saja, jumlah koloni bakteri menurun setelah penyimpanan selama 3 minggu (Gambar 1). Menurut Vigliar et al. (2006) air kelapa mempunyai komposisi nutrisi yang lengkap berupa 95,5\% air; $4 \%$ karbohidrat; $0,1 \%$ lemak; $0,02 \%$ kalsium; $0,01 \%$ fosfor; $0,5 \%$ besi, asam amino, vitamin C, vitamin B kompleks dan garam-garam mineral. Kandungan nutrisi dalam limbah air kelapa diduga mampu dimanfaatkan oleh bakteri untuk proses pembelahan sel dan mempertahankan viabilitas sel bakteri

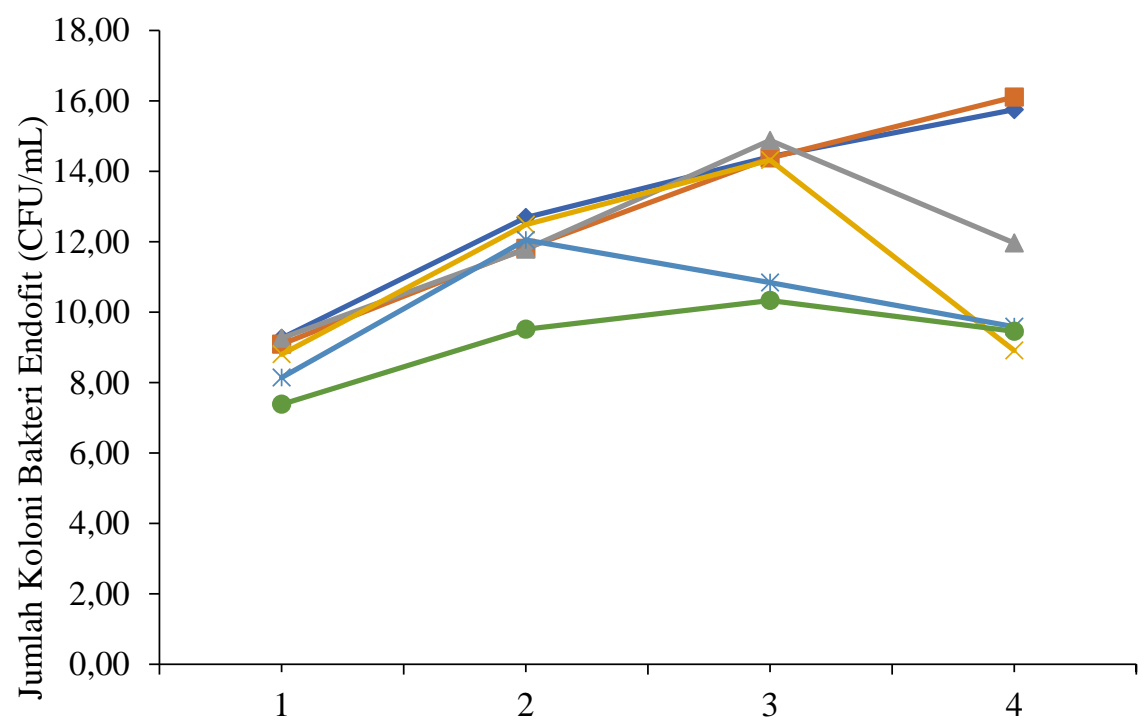

Lama Penyimpanan Media Perbanyakan Bakteri Endofit (Minggu)

$$
\begin{aligned}
& \multimap \text { EAL15 (1.000 ml Air Kelapa + } 5 \text { g Pepton) } \\
& - \text { EKK22 (1.000 ml Air Kelapa + } 5 \text { g Pepton) } \\
& \approx \text { EAL15 (100\% Air Kelapa) } \\
& \approx \text { EKK22 (100\% Air Kelapa) } \\
& \text { EAL15 (1.000 ml Akuades + } 5 \text { g Pepton) }
\end{aligned}
$$

Gambar 1. Grafik pertumbuhan koloni bakteri endofit pada beberapa media perbanyakan bakteri endofit setelah disimpan selama 1-4 minggu 

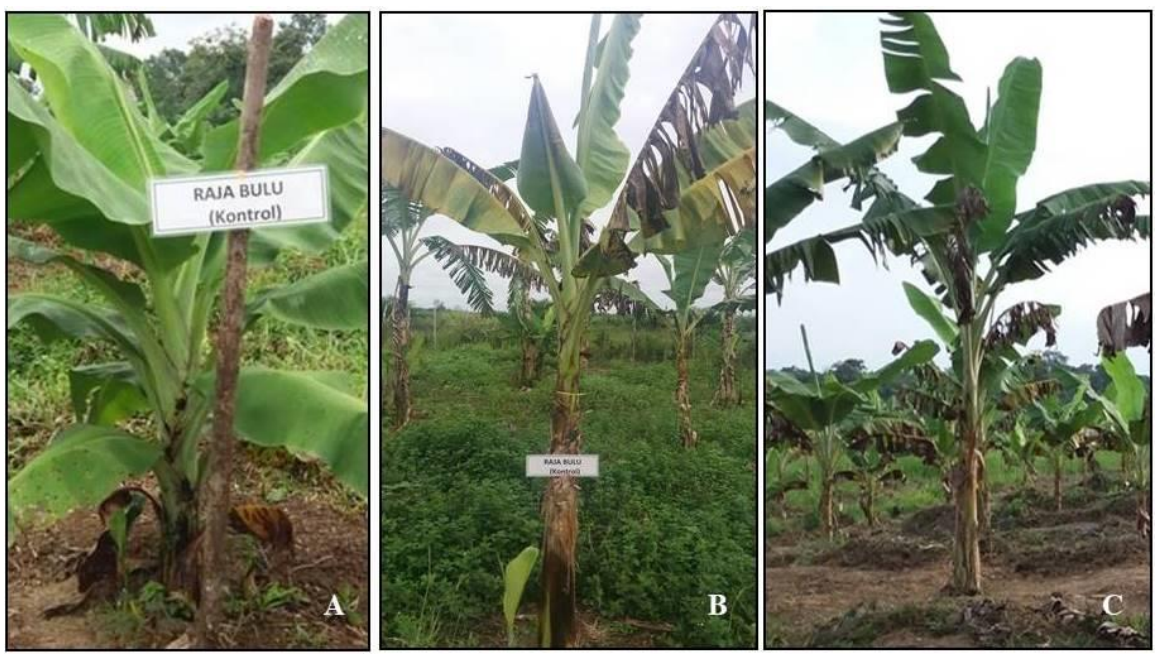

Gambar 1. Uji aplikasi bakteri endofit pada pisang Raja Bulu di lapangan : (A) Tanaman umur 3 bulan setelah tanam; (B) Tanaman bergejala penyakit darah yang diinokulasi dengan $R$. solanacearum: (C)Tanaman diinokulasi dengan air steril

\section{Pengaruh Aplikasi Bakteri Endofit Terhadap Perkembangan Penyakit Darah pada Tanaman Pisang di Lapangan}

Gejala penyakit darah pada tanaman pisang yang diinokulasi dengan $R$. solanacearum melalui perakaran tanaman muncul mulai minggu ke-1 setelah inokulasi pada tanaman kontrol, sedangkan pada tanaman yang diberi aplikasi bakteri endofit gejala mulai muncul setelah minggu ke-3 (Gambar 1).

Hasil pengamatan terhadap perkembangan penyakit darah pada tanaman pisang yang diinokulasi dengan $R$. solanacearum melalui akar tanaman pada minggu ke-4 setelah inokulasi menunjukkan bahwa aplikasi bakteri endofit berpengaruh terhadap keparahan penyakit darah pada tanaman pisang (Tabel 4). Hal yang sama juga diamati pada tanaman yang diinokulasi melalui bunga, dimana aplikasi bakteri endofit berpengaruh terhadap kejadian penyakit darah pada buah pisang (Tabel 4). Hasil pengamatan juga menunjukkan bahwa frekuensi aplikasi bakteri endofit tidak berpengaruh terhadap keparahan penyakit pada tanaman dan kejadian penyakit pada buah pisang.
Pengaruh aplikasi bakteri endofit terhadap kejadian penyakit darah pada buah pisang terlihat dari perbedaan jumlah buah yang bergejala pada masingmasing tandan pada 3 minggu setelah inokulasi. Persentasi buah pisang yang menunjukkan gejala penyakit darah pada kontrol berbeda nyata dengan buah yang diberi perlakukan bakteri endofit. Aplikasi bakteri endofit mampu menekan kejadian penyakit darah pada buah pisang Raja Bulu sebesar 74,2-83,0\% (Tabel 2).

Gejala penyakit darah diamati pada semua tandan pisang yang diinokulasi melalui bunga, baik pada perlakuan bakteri endofit maupun tanaman kontrol (Gambar 2). Hal ini menunjukkan bahwa perlakuan bakteri endofit pada akar tanaman pisang tidak mampu menghambat penetrasi patogen pada buah tanaman pisang, baik pada buah yang telah terbentuk pada saat dilakukannya inokulasi maupun pada buah yang terbentuk setelah dilakukannya inokulasi. Penurunan jumlah buah pisang yang menunjukkan gejala penyakit pada perlakuan bakteri endofit diduga terjadi karena bakteri endofit mampu mengkolonisasi buah sebelum bakteri melakukan penetrasi.

Tabel 2. Pengaruh aplikasi bakteri endofit terhadap perkembangan penyakit darah padatanaman pisang Raja Bulu yang diinokulasi melalui akar dan bunga pisang

\begin{tabular}{lcccc}
\hline Perlakuan Isolat Bakteri & \multicolumn{2}{c}{ Inokulasi patogen pada akar $(\%)$} & \multicolumn{2}{c}{ Inokulasi patogen pada bunga } \\
\cline { 2 - 5 } $\begin{array}{c}\text { Endofit dan Frekuensi } \\
\text { aplikasi }\end{array}$ & $\begin{array}{c}\text { Keparahan Penyakit } \\
(\%)\end{array}$ & $\begin{array}{c}\text { Penekanan Penyakit } \\
(\%)\end{array}$ & $\begin{array}{c}\text { Kejadian Penyakit } \\
(\%)\end{array}$ & $\begin{array}{c}\text { Penekanan Penyakit } \\
(\%)\end{array}$ \\
\hline EAL15 (1 kali) & $7,5 \mathrm{a}$ & 89,7 & $8,86 \mathrm{a}$ & 80,4 \\
EKK22 (1 kali) & $5,0 \mathrm{a}$ & 93,1 & $10,21 \mathrm{a}$ & 77,4 \\
EAL15 (2 kali) & $12,5 \mathrm{a}$ & 82,8 & $10,13 \mathrm{a}$ & 77,6 \\
EKK22 (2 kali) & $15,0 \mathrm{a}$ & 79,3 & $7,69 \mathrm{a}$ & 83,0 \\
EAL15 (3 kali) & $7,5 \mathrm{a}$ & 89,7 & $8,86 \mathrm{a}$ & 80,4 \\
EKK22 (3 kali) & $12,5 \mathrm{a}$ & 82,8 & $11,64 \mathrm{a}$ & 74,2 \\
Kontrol & $72,5 \mathrm{~b}$ & & $45,15 \mathrm{~b}$ & \\
\hline
\end{tabular}

Keterangan: Angka pada tiap kolom yang diikuti dengan huruf sama tidak berbeda nyata menurut uji DNMRT taraf 5\%. 

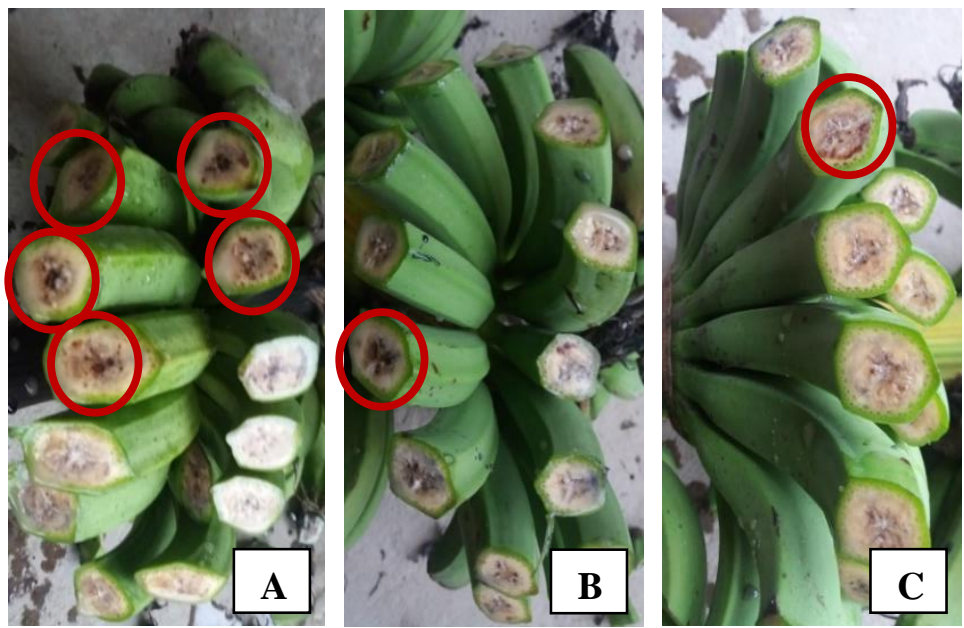

Gambar 2. Gejala penyakit darah pada buah pisang Raja Bulu yang diinokulasi dengan $R$. solanacearummelalui bunga pisang: A) Tanpa perlakuan bakteri endofit; B) Aplikasi isolat bakteri endofit EAL15; dan C) Aplikasi isolat bakteri endofit EKK22. Lingkaran merah adalah buah pisang yang menunjukkan gejala penyakit darah

Bakteri endofit yang diaplikasi pada perakaran tanaman pisang melakukan kolonisasi pada rizosfer dan semua jaringan tanaman pisang. Hasil penelitian Marwan et al. (2012) menunjukkan bahwa bakteri endofit EAL15-Rif (mutan bakteri endofit EAL-15 yang telah resisten terhadap antibiotik Rifampisin) telah terdeteksi di dalam jaringan akar pada 3 hari setelah inokulasi, sedangkan di dalam jaringan bonggol terdeteksi pada 4 minggu setelah inokulasi. Hasil analisis populasi bakteri endofit EAL15-Rif pada 3 hari setelah perlakuan menunjukkan bahwa populasi bakteri di rizosfer dan permukaan akar lebih tinggi dibandingkan dengan populasi bakteri di dalam jaringan akar berada di ruang antar sel tanaman memproduksi senyawa yang dapat mengaktifkan respon pertahanan.

Kolonisasi bakteri endofit pada buah pisang diduga mempunyai peranan penting dalam menekan infeksi bakteri $R$. solanacerum pada buah pisang. Menurut Benhamou et al. (1998), serangkaian peristiwa diamati pada sel tanaman mentimun yang diinokulasi dengan bakteri endofit Bacillus pumilus SE34, yaitu: 1) Pengembangan penghalang struktural dan produksi senyawa toksin seperti fenolik dan fitoaleksin; DAN 2) Sintesis dan akumulasi molekul lain serta enzim hidrolitik seperti $\beta-1,3$ glukanase, yang diduga berkontribusi untuk melepaskan oligosakarida dan dapat merangsang reaksi pertahanan tanaman. Benhamou et al. (2000) juga menyatakan bahwa kolonisasi bakteri endofit Serratia plymuthica pada mentimun dapat menginduksi terbentuknya penghalang struktural dan biokimia pada jaringan tanaman inangnya dan menurunkan tingkat kolonisasi dari cendawan patogen Pythium ultimum.

\section{KESIMPULAN}

Berdasarkan hasil penelitian yang telah dilakukan dapat disimpulkan: 1) Media limbah air kelapa + pepton merupakan media perbanyakan terbaik untuk pertumbuhan populasi isolat bakteri endofit EAL15 dan EKK22; 2) Aplikasi suspensi bakteri endofit berpengaruh terhadap keparahan penyakit darah pada tanaman pisang yang diinokulasi dengan inokulum $R$. solanacearum melalui akar tanaman pisang dan kejadian penyakit darah pada buah pisang yang diinokulasimelalui bunga pisang; dan 3) Intensitas aplikasibakteri endofit tidak berpengaruh terhadap keparahan penyakit darah pada tanaman dan buah pisang.

\section{UCAPAN TERIMA KASIH}

Terima kasih diucapkan kepada Direktorat Penelitian dan Pengabdian Masyarakat, Direktorat Jenderal Pendidikan Tinggi (DP2M DIKTI) yang telah mendanai kegiatan penelitian ini melalui skim Penelitian Pengembangan IPTEK.

\section{DAFTAR PUSTAKA}

Agrios, G.N. 2005. Plant Pathology. 5th Edition. New York: Academic Press.

Bashan, Y. and L.E. de-Bashan. 2005. Bacteria, plant growth-promoting. In: Encyclopedia of Soil in The Environment. (Editor-in-chief) D. Hiller, Elsevier Oxford UK. Pp. 103-115.

Benhamou, N., J.W. Kloepper, and S. Tuzun. 1998. Induction of resistance against Fusarium wilt of tomato by combination of chitosan with an endophytic bacterial strain: ultrastructure and cytochemistry of the host response. Planta 204: 153-168. DOI: $10.1007 / \mathrm{s} 004250050242$.

Benhamou, N., S. Gagné, D. Le Quéré, and L. Dehbi. 2000. Bacterial-mediated induced resistance in Cucumber: Beneficial effect of the endophytic bacterium Serratia plymuthica on the protection against infection by Pythium ultimum. 
Phytopathology 90: 45-56. DOI: 10.1094/PHYTO.2000.90.1.45.

Buddenhagen, I.W. and T.A. Elsaser. 1962. An insectspread bacterial wilt epiphytotic of bluggue banana. Nature 194: 164-165. DOI: 10.1038/194164a0.

Fegan, M. and P. Prior. 2006. Diverse members of the Ralstonia solanacearum species complex cause bacterial wilts of banana. Australasian Plant Pathology 35: 93-101. DOI: 10.1071/AP05105.

Hadiwiyono. 2010. Penyakit darah pada tanaman pisang: Infeksi dan keanekaragaman genetika pathogen. Disertasi. Universitas Gadjah Mada. Yogyakarta.

Hallmann, J. 2001. Plant Interaction with Endophytic Bacteria. In: Jeger, M.J. and N.J. Spence (Editors). Biotic Interaction in Plant-Pathogen Associations. CAB International.

Harish, S., M. Kavino, N. Kumar, D. Saravanakumar, K. Soorianathasundaram, and R. Samiyappan. 2008. Biohardening with plant growth promoting rhizosphere and endophytic bacteria induce systemic resistance against banana bunchy top virus. Applied Soil Ecology 39: 187-200. DOI: j.apsoil.2007.12.006.

Hermanto, C., Eliza, and D. Emilda. 2013. Bunch management of banana to control blood disease. Australasian Plant Pathology 42: 653-658. DOI: 10.1007/s13313-013-0248-5.

Hurek, T., L.L. Handley, B. Reinhold-Hurek, and Y. Piche. 2002. Azoarcus grass endophytes contribute fixed nitrogen to the plant in an unculturable state. Molecular Plant-Microbe Interactions 15: 233-242. DOI: 10.1094/MPMI.2002.15.3.233.

Lian, J., Z. Wang, and S. Zhou. 2008. Response of endophytic bacterial communities in banana tissue culture plantlets to Fusarium wilt pathogen infection. The Journal of Genetic and Applied Microbiology 54: 83-92. DOI: 10.2323/jgam.54.83.

Marwan, H. 2014. Pengimbasan ketahanan tanaman pisang terhadap penyakit darah $(R$. solanacearum Phylotipe IV) menggunakan bakteri endofit. Jurnal Hama dan Penyakit Tumbuhan Tropika 14: 128-135. DOI: 10.23960/j.hptt.214128-135.

Marwan, H., M.S. Sinaga, Giyanto, dan A.A. Nawangsih. 2011. Isolasi dan seleksi bakteri endofit untuk pengendalian penyakit darah pada tanaman pisang. Jurnal Hama dan Penyakit Tumbuhan Tropika 11: 112-119. DOI: 10.23960/j.hptt.211113-121.

Marwan, H., M.S. Sinaga, Giyanto, dan A.A. Nawangsih. 2012. Potensi bakteri endofit sebagai agens pengendalian hayati penyakit darah pada tanaman pisang. Disertasi Sekolah Pascasarjana IPB. Bogor.

Semangun, H. 2000. Penyakit-penyakit Tanaman Hortikultural di Indonesia. Yogyakarta: Gajahmada University Press.

Sessitsch, A., B. Reiter, and G. Berg. 2004. Endophytic bacterial communities of field-grown potato plants and their plant-growth-promoting and antagonistic abilities. Canada Journal Microbiology 50: 239-249. DOI: 10.1139/w03118.

Supriadi. 2005. Present Status of Blood Disease in Indonesia. In: Allen C, Prior P, Hayward AC editor. Bacterial Wilt Disease and the Ralstonia solanacearum complex. Minnesota: APS Press. Pp. 395-404.

Vigliar, R., V.L. Sdepanian, and U. Fagundes-Neto. 2006. Biochemical profile of coconut water from coconut palms planted in an inland region. Jornal de Pediatria 82: 308-312. DOI: 10.2223/JPED.1508. 